\title{
Anti-tumor effects of cimetidine on hepatocellular carcinomas in diethylnitrosamine-treated rats
}

\author{
KOICHIRO FURUTA ${ }^{1}$, SHUICHI SATO ${ }^{1}$, TATSUYA MIYAKE ${ }^{2}$, EISUKE OKAMOTO ${ }^{1}$, JUNICHI ISHINE ${ }^{1}$, \\ SHUNJI ISHIHARA $^{1}$, YUJI AMANO ${ }^{2}$, KYOICHI ADACHI ${ }^{1}$ and YOSHIKAZU KINOSHITA $^{1}$ \\ ${ }^{1}$ Department of Gastroenterology and Hepatology, Shimane University School of Medicine; ${ }^{2}$ Division of Endoscopy \\ and Ultrasonography, Shimane University Hospital, 89-1 Enya-cho, Izumo, Shimane 693-8501, Japan
}

Received August 27, 2007; Accepted October 22, 2007

\begin{abstract}
Cimetidine is known to have an anti-tumor effect on certain types of malignancies, though on hepatocellular carcinomas (HCCs), its effect remains unclear. We studied the anti-tumor effects of cimetidine on chemically-induced HCCs in rats. Four-week-old male Wistar rats $(n=105)$ were divided into 4 groups. Those in groups A and B were administered diethylnitrosamine (DEN) intraperitoneally at $100 \mathrm{mg} / \mathrm{kg}$ body weight every week for 6 weeks, during which rats in group A were given tap water and those in group B received cimetidine (100 $\mathrm{mg} / \mathrm{kg} /$ day) in their drinking water. Rats in groups $\mathrm{C}$ and $\mathrm{D}$ were administered saline instead of DEN and given tap water with 100 $\mathrm{mg} / \mathrm{kg}$ /day of cimetidine, respectively. The animals were sacrificed at $7,12,22$ and 32 weeks after the first administration of drugs and examined. Liver nodules were observed only in groups A and B, with the number of nodules, maximum diameter of the largest nodule, and liver weight significantly lower in group B. Immunohistochemistry findings showed that glutathione S-transferase placental-positive preneoplastic foci were significantly decreased in group B. Cimetidine treatment decreased the number of proliferating cell nuclear antigen-positive hepatocytes and tended to enhance natural killer (NK) cell activity in splenic lymphocytes. In addition, flow cytometry revealed that the proportion of NK cells among total splenic lympocytes was not affected by cimetidine treatment. Our results showed that cimetidine has an inhibiting effect on hepatocarcinogenesis.
\end{abstract}

\section{Introduction}

Hepatocellular carcinoma (HCC) is currently the fifth most commonly occurring type of cancer and the third leading cause of death from cancer worldwide (1). Most patients with

Correspondence to: Dr Koichiro Furuta, Department of Gastroenterology and Hepatology, Shimane University School of Medicine, 89-1 Enya-cho, Izumo, Shimane 693-8501, Japan

E-mail: furuta@med.shimane-u.ac.jp

Key words: cimetidine, hepatocellular carcinomas, hepatocarcinogenesis, diethylnitrosamine
HCC also suffer from liver cirrhosis, which is the major risk factor for HCC, mainly caused by infection with either the hepatitis B virus (HBV) or the hepatitis C virus (HCV) (2). Ursodeoxycholic acid (3) and glycyrrhizin (4) have been reported to be effective in preventing liver carcinogenesis, while recently the preventive effects of vitamin K2 (5) and acyclic retinoid (6) towards recurrence in patients with $\mathrm{HCC}$ have been reported. Nevertheless, HCCs frequently occur in patients with $\mathrm{HCV}$ cirrhosis at an annual rate of $\sim 8 \%$ in Japan, with recurrence within 5 years seen in $70 \%$ of cases (7). Interferon therapy prevents the incidence of $\mathrm{HCC}$ in patients with HCV-related cirrhosis (8), however, it is somewhat difficult to use in cases of uncompensated cirrhosis or serious complications, because of its many adverse effects. It is important to develop safe and more effective chemopreventive drugs for treatment of hepatocarcinogenesis.

Cimetidine was first developed in 1974 as a histamine $\mathrm{H}_{2}$ receptor antagonist and its anti-tumor effect was initially reported in 1979 by Armitage and Sidner, who reported 2 cases of metastatic cancer with complete remission following administrations of cimetidine (9). In 1988, it was reported that post-operative treatment with cimetidine improved survival in a gastric cancer patient (10). Since that time, several studies have reported survival advantages with cimetidine treatment, mainly in patients with gastrointestinal cancer (11-14). Further, positive effects have also been demonstrated in non-gastrointestinal cancer patients, such as those with renal cell carcinoma (15), malignant melanoma (16) and glioblastoma (17).

In contrast, there has been no clinical study of the antitumor effects of cimetidine in patients with HCC, though Fujikawa et al recently reported results of an in vitro study. Their findings indicated that cimetidine inhibited cell proliferation and migration induced by an epidermal growth factor (EGF) in HCC cell lines (18). In the present study, we studied the anti-tumor effects of cimetidine on chemically induced HCCs in rats.

\section{Materials and methods}

Animals. A total of 105 four-week-old male Wister rats were obtained from Charles River Japan (Yokohama, Japan) and maintained at a controlled room temperature with a 12-h light/dark illumination cycle. All rats were housed in wire 


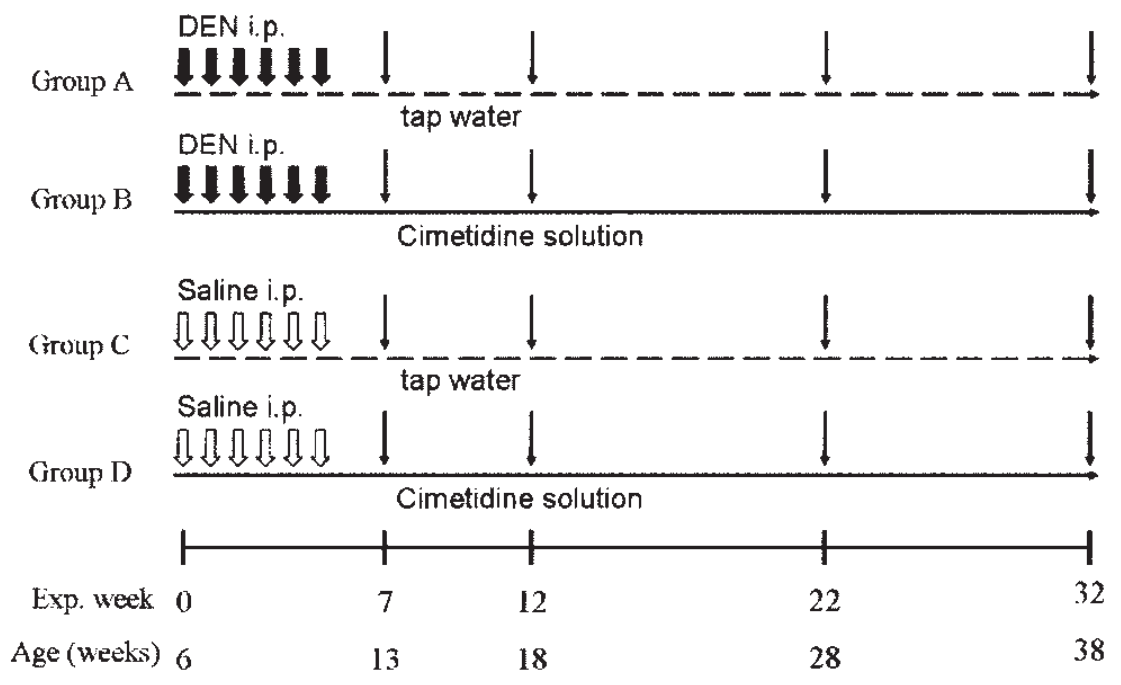

Figure 1. Experimental design. DEN (100 mg/kg body weight) was administered to rats in groups A ( $\mathrm{n}=25)$ and $\mathrm{B}(\mathrm{n}=27)$, while saline was administered to rats in groups $C(n=27)$ and $D(n=26)$ intraperitoneally once a week for 6 weeks. In addition, rats in groups B and D received cimetidine (100 mg/kg/day) in their drinking water, while those in groups $\mathrm{A}$ and $\mathrm{C}$ received tap water alone for drinking. DEN and cimetidine treatment were started at the same time. The rats were sacrificed $(\downarrow)$ at $7,12,22$ and 32 weeks after the first administration of drugs.

cages (3-5 rats/cage), with MF (Oriental Yeast, Tokyo, Japan) given as a basal diet. The animal experimental protocol was approved by the Institute for Animal Experimentation of Shimane University and conducted in accordance with its guidelines.

Experimental schedules. The experimental design is shown in Fig. 1, which was a modification of a protocol for diethylnitrosamine (DEN)-induced chemical hepatocarcinogenesis, as described previously (19). On arrival, the rats were quarantined and, after a 2-week adaptation period, divided into 4 groups for the experiment. Rats in group A $(n=25)$ were allowed free access to tap water, while those in group B $(\mathrm{n}=27)$ received cimetidine (Dainippon Sumitomo Pharma, Osaka, Japan) (100 mg/kg/day) in their drinking water during the experimental period. In order to provide $100 \mathrm{mg} / \mathrm{kg} / \mathrm{day}$ of cimetidine to the group B rats, drinking water volume and body weight were monitored twice a week from the beginning of the adaptation periods to the end of the experiment, with the appropriate concentration of cimetidine in drinking water calculated each time. In both groups, DEN (Nakarai Tesque, Kyoto, Japan) at $100 \mathrm{mg} / \mathrm{kg}$ of body weight was administered intraperitoneally once a week for 6 weeks from the start of the experiment. Rats in group $\mathrm{C}(\mathrm{n}=27)$ were given tap water and those in group $D(n=26)$ were given cimetidine in their drinking water, with saline administered intraperitoneally once a week for 6 weeks to both groups. In rats that received them, DEN and cimetidine treatments were started at the same time. The rats were sacrificed under ether anesthesia at 7, 12, 22, and 32 weeks after beginning the experiment. A blood sample was taken from the right atrium and the livers were removed, weighed and fixed in $10 \%$ buffered formalin. Fixed livers were sliced into 3-mm sections and the numbers and sizes of liver nodules were determined, with nodules $>3 \mathrm{~mm}$ in diameter and counted for later analysis. The liver slices were embedded in paraffin blocks, stained with hematoxylin and eosin, and used for immunohistochemical studies. Doses of
$100 \mathrm{mg} / \mathrm{kg} /$ day of cimetidine have been reported to produce serum levels of $0.16-0.35 \mu \mathrm{g} / \mathrm{ml}$ and inhibit the growth of tumor xenografts in experimental mice (20). This serum level range is comparable with the level in a human receiving $300 \mathrm{mg}$ orally (21).

Laboratory tests. Serum aspirate aminotransferase (AST), alanine aminotransferase (ALT), alkaline phosphatase (ALP), and lactate dehydrogenase $(\mathrm{LDH})$ were measured by a consensus method recommended by the Japanese Society of Clinical Chemistry (JSCC). The assay was conducted by SRL Inc. (Tokyo, Japan).

Immunohistochemistry. Liver tissues from a portion of the left lobe (22) were used for immunohistochemical studies. Fixed sections were deparaffinized with xylene and incubated with $3 \% \mathrm{H}_{2} \mathrm{O}_{2}$. Then, the sections were incubated with rabbit antiglutathione S-transferase placenta (GST-P) polyclonal antibody (MBL, Nagoya, Japan) diluted at 1:1000 for $30 \mathrm{~min}$, followed by incubation with the secondary antibody using a Dako ChemMate EnVision kit/HRP (Dako Japan, Kyoto, Japan). The bound antibody was detected by incubating the slides with AEC (Dako Cytomation, Kyoto, Japan). Then, double-staining for proliferating cell nuclear antigen (PCNA) and GST-P was performed using a Vectastain ABC kit (Vector Laboratories, Burlingame, CA, USA). The sections were subjected to heat-induced antigen retrieval in distilled water at $121^{\circ} \mathrm{C}$ for $30 \mathrm{sec}$. After incubation with normal horse serum for $30 \mathrm{~min}$, the sections were incubated with mouse antiPCNA monoclonal antibody (Dako Cytomation) diluted at 1:500 for $30 \mathrm{~min}$. They were then incubated with secondary biotinylated anti-mouse immunoglobulin $\mathrm{G}$ for $20 \mathrm{~min}$, followed by incubation with alkaline phosphatase-labeled avidin-biotin complex solution for $20 \mathrm{~min}$. The bound antibodies were detected by incubating the slides with BCIP/NBT (Dako Cytomation), then the sections were counter-stained with hematoxylin. The total amount of pre- 


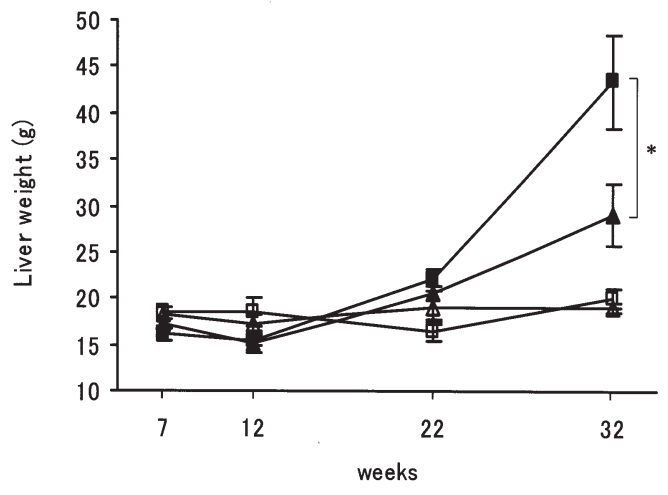

Figure 2. Changes in liver weights. The liver weight in group B was

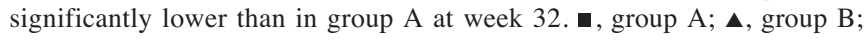
$\square$, group $\mathrm{C}$; $\triangle$, group $\mathrm{D} ;{ }^{*} \mathrm{p}<0.05$.

neoplastic foci was expressed as the area of GST-P-positive cells in the histological sections, calculated with image analyzing software (NIH image; Wayne Rasband, National Institutes of Health, USA). The number of PCNA-positive cells in each section was evaluated by determining the percentage of positive nuclei in at least 1,000 cells.

Preparation of splenic lymphocytes. Splenic lymphocytes were isolated using a density gradient centrifugation method. The spleens were removed and excised, then finely minced in Hanks' Balanced Salt Solution (HBSS) (Gibco-Invitrogen, Tokyo, Japan). Then, the suspension was passed through a $40-\mu \mathrm{m}$ cell strainer (Becton Dickinson, Tokyo, Japan) and the cell concentration adjusted to $\sim 2 \times 10^{7}$ cells per ml. Five milliliters of the cell suspension was carefully layered over the top of $5 \mathrm{ml}$ of Lympholate-Rat (Cedarlane Labs, Hornby, Ontario, Canada) in 15-ml centrifuge tubes. The tubes were centrifuged for $20 \mathrm{~min}$ at $1500 \mathrm{x} \mathrm{g}$ at room temperature, and the white cell layer was carefully removed using a Pasteur pipette and transferred to a new tube. These cells were washed with phosphate-buffered saline (PBS) (Nissui, Tokyo, Japan) and cultured in a complete medium consisting of RPMI-1640 (Gibco-Invitrogen), 10\% heat-inactivated fetal bovine serum (ICN Biomedicals Inc., OH, USA), and a $1 \%$ antibiotic/ antimicotic solution (Gibco-Invitrogen).

Cytotoxicity test. Cytotoxicity tests were performed using splenic lymphocytes collected on week $28(n=4$ rats in each group) with a ${ }^{51} \mathrm{Cr}$ releasing assay. YAC-1 cells, kindly provided by the Cell Resource Center for Biochemical Research, Institute of Development, Aging and Cancer, Tohoku University, were used as target cells. YAC-1 cells $\left(2 \times 10^{6}\right)$ were labeled with $3.7 \mathrm{MBq}$ of $\mathrm{Na}_{2}{ }^{51} \mathrm{CrO}_{5}$ (MP Biomedicals, Irvine, CA) at $37^{\circ} \mathrm{C}$ for $1 \mathrm{~h}$ in a shaking water bath. Labeled target cells were washed with PBS and adjusted to $1 \times 10^{5} / \mathrm{ml}$ in a complete medium, then seeded at a concentration of $1 \times 10^{4}$ cells/well in micro-well plates. The effector cells (lymphocytes) were added to the wells at effector to target (E:T) ratios of 100:1, 50:1, and 25:1 in a total volume of $200 \mu 1$. Spontaneous release was determined from wells containing labeled target cells and $100 \mu 1$ of complete medium. Maximum release was obtained by treating the target cells with $100 \mu \mathrm{l}$ of $1 \mathrm{~N} \mathrm{HCl}$. All assays were performed in triplicate. After incubation at $37^{\circ} \mathrm{C}$ for $4 \mathrm{~h}$, the plate was centrifuged. Subsequently, $100 \mu 1$ of supernatant was aspirated from each well and ${ }^{51} \mathrm{Cr}$ release was determined in a $\gamma$ counter (Aloka ARC-2000, Tokyo, Japan). The results are expressed as percent lysis according to the following formula: percent lysis $=[$ (sample release - complement control release $) /$ (maximum release - complement control release)] x100\%.

Flow cytometry. The proportion of natural killer (NK) cells among splenic lymphocytes was examined by flow cytometry $(n=4$ rats in each group). Isolated splenic lymphocytes were stained with the monoclonal antibodies fluorescein isothiocyanate (FITC)-conjugated mouse anti-rat CD161 (Immunotech, Marseilles, France) and phycoerythrin (PE)conjugated mouse anti-rat CD45 (Immunotech), diluted appropriately and according to the manufacturer's instructions. Cells were gated as determined by forward- and side-scatter criteria to avoid potential contamination by dead cells or debris. Analysis of stained cells was performed using a Beckman Coulter Epics XL, with data analyzed using Expo32 software.

Statistical analysis. All data are represented as the mean \pm SE. Statistical comparisons between two groups were conducted with a Mann-Whitney U-test. Multiple comparisons were conducted with one-way factorial ANOVA, followed by a post-hoc multiple comparison analysis. $\mathrm{P}<0.05$ was considered statistically significant.

\section{Results}

Liver weight. Liver weights were gradually increased in the DEN-treated groups (A and B), though those in group B were significantly lighter at week $32(43.5 \pm 5.0 \mathrm{~g}$ in group A, $29.1 \pm 3.4 \mathrm{~g}$ in group B, p<0.05; Fig. 2). The average ratio of the liver weight to total body weight showed a similar tendency as the liver weights (data not shown).

Laboratory tests. Serum ALT levels in the DEN-treated groups (A and B) were higher than those in the non-treated groups ( $\mathrm{B}$ and $\mathrm{C}$ ) throughout the experiment. However, serum ALT levels in group B were significantly lower than those in group A at week $32(81.3 \pm 4.0 \mathrm{IU} / 1$ in group A, $66.3 \pm 4.3 \mathrm{IU} / 1$ in group $\mathrm{B}, \mathrm{p}<0.05)$. A similar tendency was also found for serum AST, LDH, and ALP, though there were no statistically significant differences between groups A and B (data not shown).

Macroscopic findings for liver nodules. Liver nodules were observed in the DEN-treated groups (A and B) at week 12, 22, and 32 (Fig. 3A and B). Histological diagnoses of the liver nodules were made according to criteria reported by Squire and Levitt (23), which showed the present nodules to be neoplastic or hepatocellular carcinoma. No liver nodules were observed in groups $\mathrm{C}$ and $\mathrm{D}$. The number of liver nodules in group B was less as compared to group A, with a significant difference at week $22(26.8 \pm 7.1$ nodules/liver and $5.4 \pm 2.2$ nodules/liver, respectively, $\mathrm{p}<0.05$; Fig. 3C). Further, the maximum diameter of the largest nodule in 
A

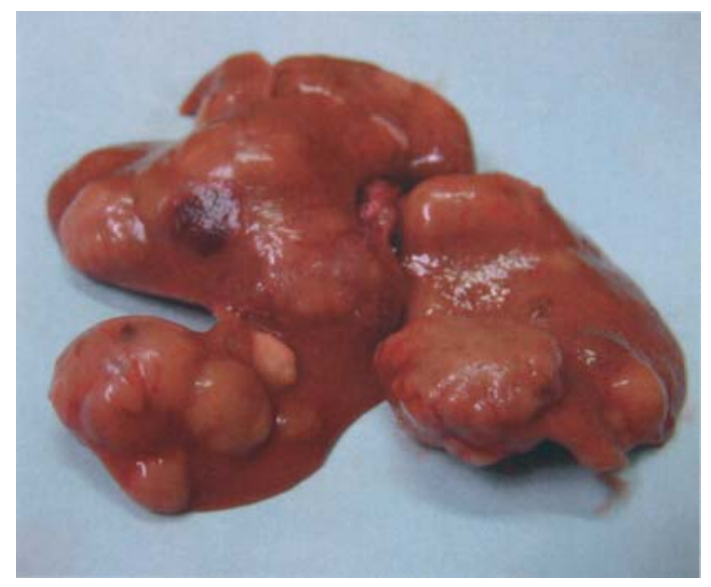

C

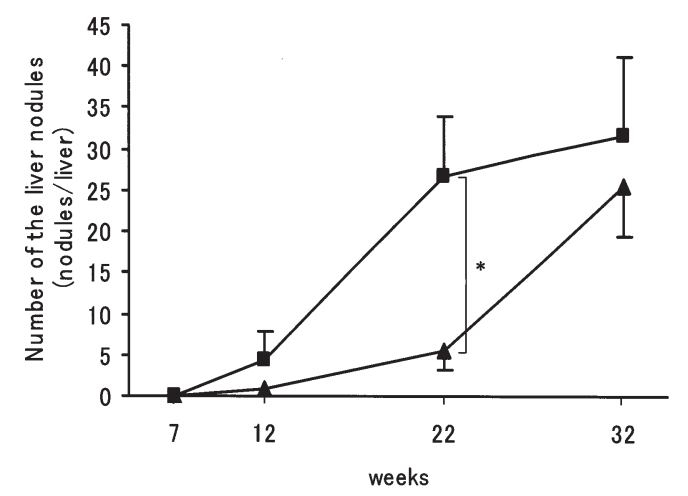

B

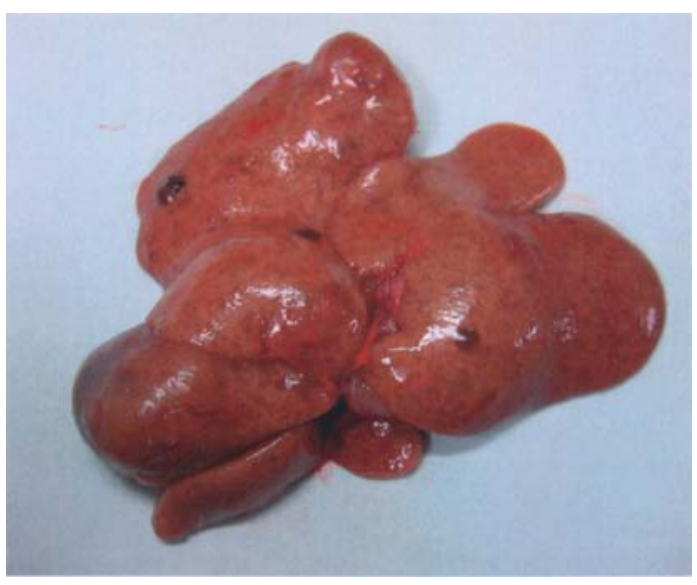

D

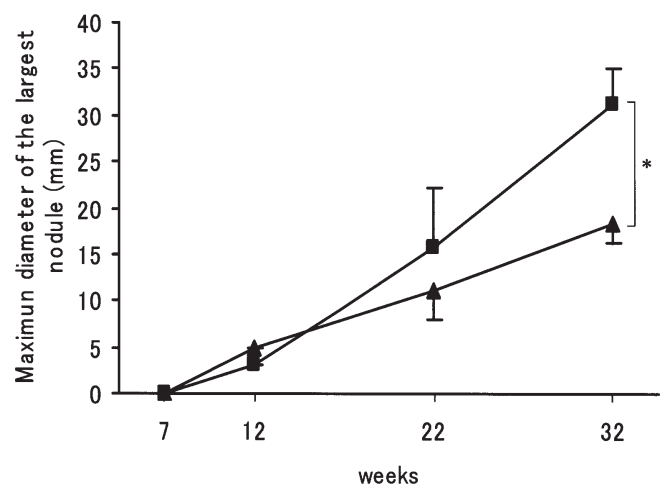

Figure 3. Macroscopic appearance. Liver nodules at week 32 in groups A (A) and B (B). (C) The number of liver nodules in group B was lower. (D) The

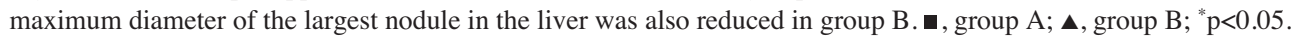

group B was also smaller than that in group A, with a significant difference found at week $32(31.3 \pm 3.9 \mathrm{~mm}$ and $18.4 \pm 2.1 \mathrm{~mm}$, respectively, p<0.05; Fig. 3D).

Immunohistochemical analysis. GST-P-positive hepatocytes were observed from week 7 in groups A and B, and the areas with GST-P-positive hepatocytes gradually expanded over time (Fig. 4A and B). In contrast, GST-P-positive hepatocytes were few in groups $\mathrm{C}$ and $\mathrm{D}$, and only seen at week 32 $(0.03 \pm 0.02 \%$ and $0.05 \pm 0.04 \%$, respectively). The GST-Ppositive area was significantly smaller in group B as compared with group A at week $22(14.1 \pm 3.4 \%$ and $27.2 \pm 3.9 \%$, respectively, $\mathrm{p}<0.05)$ and week $32(15.1 \pm 3.3 \%$ and $30.8 \pm 3.9 \%$, respectively, p<0.05) (Fig. 4E). Further, PCNApositive hepatocytes were observed in both GST-P-positive and negative areas (Fig. 4C and D), though the percentage of PCNA-positive hepatocytes was higher in the GST-Ppositive areas. In addition, the percentage of PCNA-positive hepatocytes in both GST-P-positive and negative areas in each period tended to be lower in group B than in group A, though the differences were not statistically significant (Fig. 4F).

Cytotoxicity tests. Cytotoxicity tests were performed using spleen cells with a ${ }^{51} \mathrm{Cr}$ releasing assay at week 28 . The percent lysis in group A was the lowest, while that in group B was the second highest among the 4 groups. In rats not treated with DEN, the percent lysis in group D was higher as compared to group C, though the difference was not significant (Fig. 5).

Flow cytometric study. The proportion of NK cells among total splenic lymphocytes was analyzed by flow cytometry, with representative results from a group A rat shown in Fig. 6A. The percentage of CD161-positive cells among CD45-positive cells was not significantly different among the 4 groups $(23.32 \pm 3.79 \%$ in group A, $23.32 \pm 2.94 \%$ in group B, $21.14 \pm 2.25 \%$ in group C, $21.12 \pm 2.40 \%$ in group D; Fig. 6B).

\section{Discussion}

Cimetidine is widely used to treat peptic ulcers and has also been shown to have clinical benefits in cancer patients. Previous studies have identified anti-tumor effects and a number of mechanisms of activity, such as direct inhibition of tumor growth, stimulation of host immune response and inhibition of cancer cell adhesion to endothelial cells.

Cimetidine may have a direct inhibiting effect on tumor cell growth by blocking the cell growth activity of histamine, which is known to be a growth factor, with high concentrations in some types of cancer $(24,25)$. The presence of a large number of mast cells, which produce histamine, in colorectal 
A

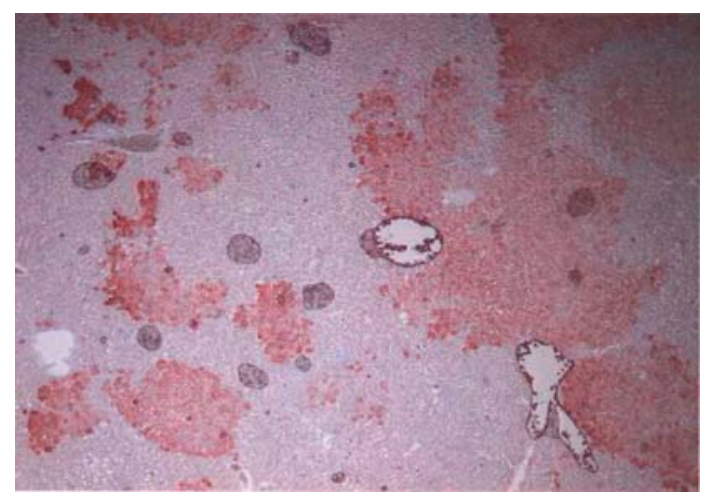

C

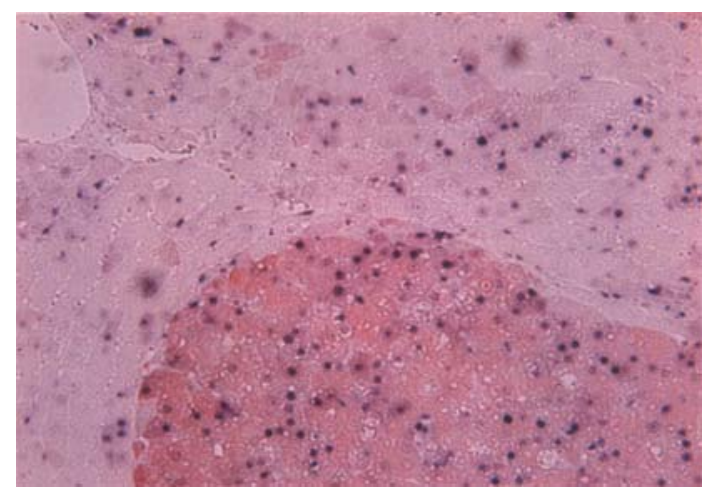

$\mathbf{E}$

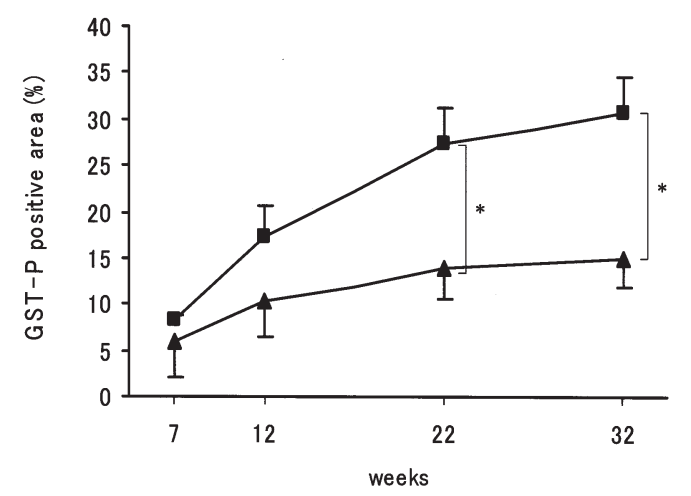

G

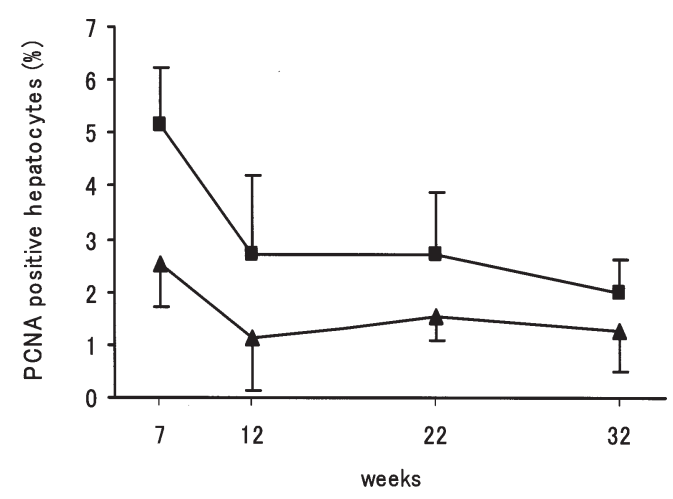

cancer tissue was shown to be associated with a worsened prognosis in patients (26). Adams et al reported that histamine stimulated the proliferation of human colorectal tumor cell lines, which was inhibited by cimetidine treatment, though cimetidine did not affect the basal proliferating ability of
B

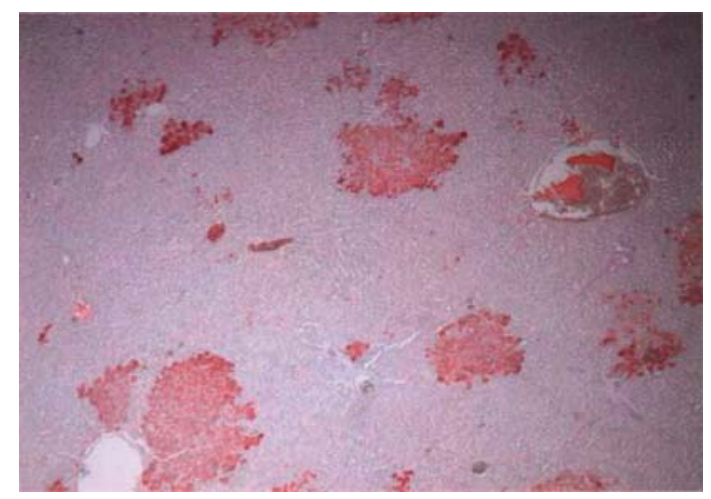

D

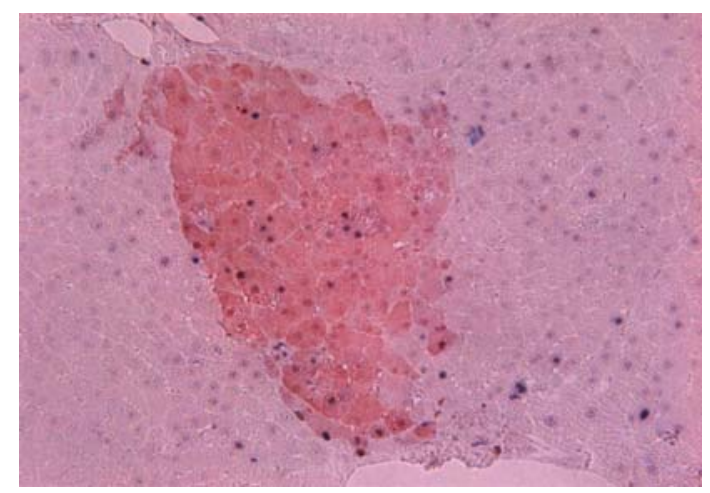

$\mathbf{F}$

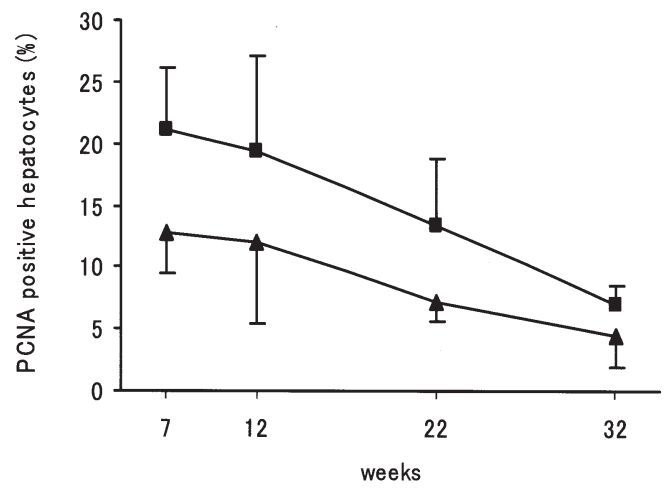

Figure 4. Immunohistochemical findings. GST-P staining at week 22 in groups A (A) and B (B) (magnification $\mathrm{x} 40$ ). Double staining with PCNA and GST-P at week 12 in groups A (C) and B (D) (magnification x100). (E) Proportions of GST-P-positive areas in microscopic fields of liver tissues. The areas of GST-P-positive hepatocytes gradually expanded over time in groups $\mathrm{A}$ and $\mathrm{B}$, though those in group B grew at a slower rate. $\mathbf{m}$, group A; $\mathbf{\Lambda}$, group $\mathrm{B}$; ${ }^{*} \mathrm{p}<0.05$. (F) Rates of PCNA-positive hepatocytes in GST-P-positive areas. (G) Rates of PCNA-positive hepatocytes in GST-P-negative areas. PCNA-positive hepatocytes in both GST-P-positive and negative areas tended to be lower in group B than in group A. $\mathbf{m}$, group A; $\mathbf{\Lambda}$, group B.

these cell lines in the absence of histamine (27). Previously, we used a ${ }^{3} \mathrm{H}$-methyl-thymidine incorporation assay with human HCC cell lines (HepG2 and KYN-2). Our results showed that a high concentration of histamine $\left(10^{-6}\right.$ to $\left.10^{-4} \mathrm{M}\right)$ stimulated the proliferation of HCC cell lines, while 


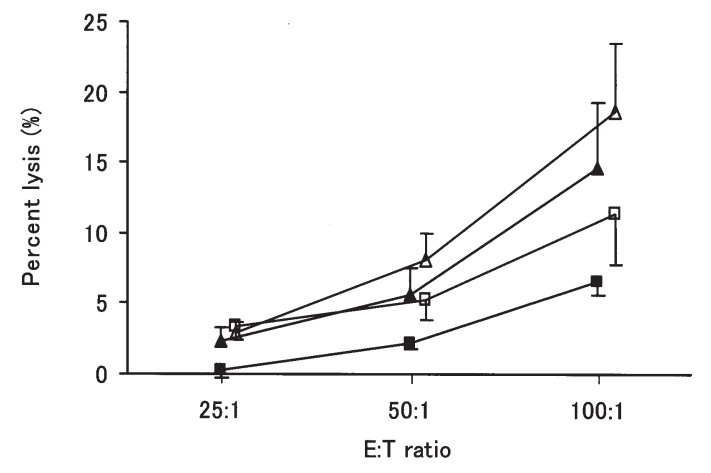

Figure 5. Cytotoxicity assay of splenic lymphocytes performed at different $\mathrm{E}: \mathrm{T}$ ratios using a ${ }^{51} \mathrm{Cr}$ releasing assay. YAC-1 cells were used as the target cells and 4 rats from each group were evaluated. The percentage of lysed cells tended to be enhanced by cimetidine administration in both groups of DENtreated rats $(\mathrm{A}, \mathrm{B})$, with that in group $\mathrm{B}$ greater than in group $\mathrm{A}$, as well as in rats not treated with DEN (C,D), with that in group D greater than in

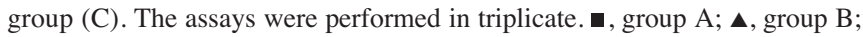
$\square$, group $C$; $\triangle$, group D.

cimetidine tended to inhibit cell growth stimulated by histamine, but did not have an effect on the basal proliferating ability of the cell lines (data not shown). In a study of Lhistidine decarboxylase (HDC)-deficient mice, which lack the capability to synthesise endogenous histamine, Takahashi et al reported that cimetidine did not suppress the growth of colon cancer xenografts, whereas suppression was observed in wild-type mice (28).

Together, these findings suggest that the anti-tumor effects of cimetidine require a stimulating effect of histamine toward tumor cell growth, which is mediated via histamine $\mathrm{H}_{2}$ receptors on tumor cells. However, other $\mathrm{H}_{2}$ receptor antagonists such as ranitidine and famotidine did not exert anti-tumor effects in previous in vitro and in vivo studies, despite their stronger acid-inhibiting activity as compared to cimetidine (29-31). In a cell proliferating assay previously performed, famotidine did not have an effect on either histamine-stimulated or basal proliferation of HCC cell lines (data not shown), which shows that the mechanisms of the inhibitory effects of cimetidine on tumor cell proliferation are not limited to blocking the $\mathrm{H}_{2}$ receptor. Recently, Fujikawa et al reported that cimetidine inhibited cell proliferation by blocking the epidermal growth factor receptor (EGFR) pathway in HCC cell lines (18).

Cimetidine has demonstrated immunomodulatory effects in a number of studies (32-36), while histamine has been shown to have immunosuppressive effects $(37,38)$. These results suggest that the effect of cimetidine on immunity is mediated by blocking the immunosuppressive effect of histamine via the $\mathrm{H}_{2}$ receptor. However, other $\mathrm{H}_{2}$ receptor antagonists possess no immunomodulatory effects, and no inhibitory effect on tumor cell proliferation as noted above. Hahm et al (39) reported comparative data regarding the immunomodulatory effects of various $\mathrm{H}_{2}$ receptor antagonists, including cimetidine, ranitidine, and famotidine, on peripheral blood mononuclear cells in patients with gastric cancer. Their findings showed that the strongest immuno-modulatory substance among these $\mathrm{H}_{2}$ receptor antagonists was cimetidine, while famotidine had the lowest effect. They speculated that the results were due to structural differences, i.e., ranitidine and famotidine lack imidazole nuclei, which are common to cimetidine. Their findings also suggested that $\mathrm{H}_{2}$ receptors, which are present on immune cells, are structurally different from those present on gastric parietal cells (40).

NK cell activity has been measured and proposed as a possible mechanism of the immunomodulatory effects of cimetidine $(41,42)$. Further, it was reported that low NK cell activity in patients with liver cirrhosis increased the risk of hepatocarcinogenesis (43), and caused early development of and invasion by HCCs (44), while preoperative NK cell activity was found to have an influence on recurrence and prognosis after hepatectomy procedures in patients with HCC (45). Lee et al studied changes of NK cell activity in DENinduced hepatocarcinogenesis model rats and demonstrated that the activity was significantly decreased in comparison with untreated control rats at 30 weeks after the first administration, while there was no difference before that time point (46). Since DEN-induced immunosuppression is considered to occur at a later stage, we evaluated the NK cell
A

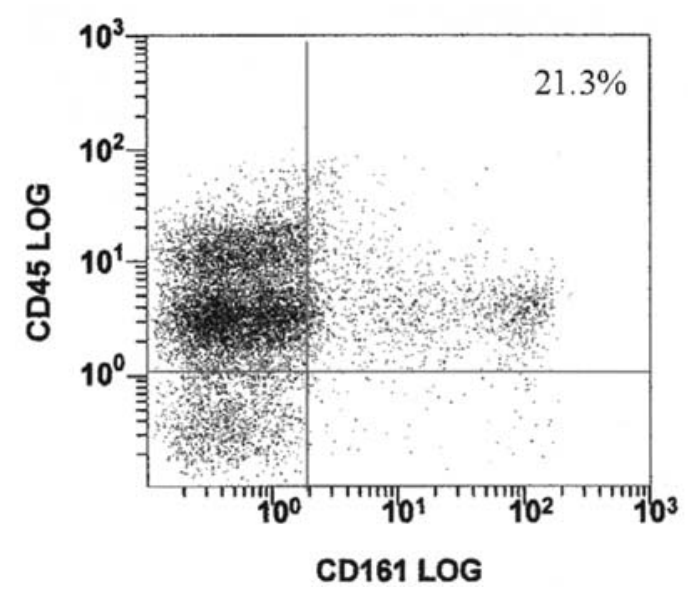

B

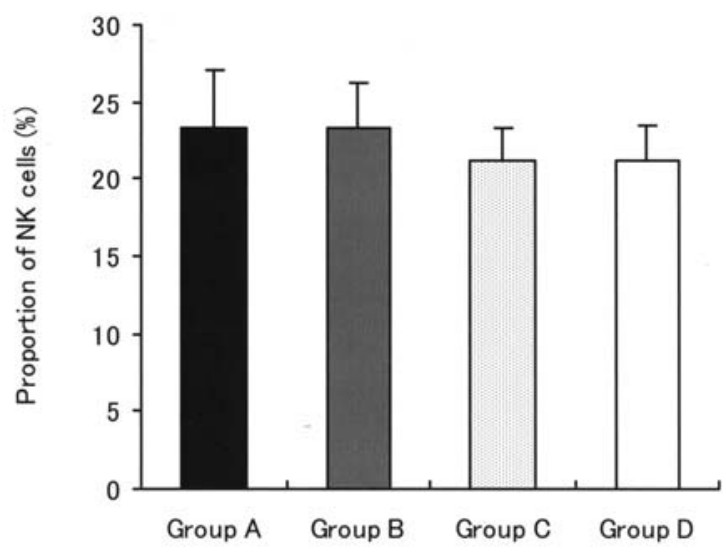

Figure 6. Proportion of NK cells in splenic lymphocytes ( $\mathrm{n}=4$ rats from each group). (A) Flow cytometric analysis of double staining for CD161 (x-axis) and CD45 (y-axis) cells in group A. Double-positive cells are represented in the upper-right quadrangle as the population of NK cells. (B) There were no significant differences among the 4 groups. 
activity of rats at week 28 and the results suggested that cimetidine increases NK cell activity that was previously reduced by DEN treatment. In addition, an increase in NK cell activity was also observed in rats not treated with DEN, though the difference was not statistically significant. We determined NK cell activity with a cytotoxicity test using total splenic lymphocytes, which consist of many kinds of lymphocytes and NK cells. Consequently, we also evaluated the proportion of NK cells among total lymphocytes using flow cytometry. CD161-positive cells (NK cells) accounted for $20 \%$ of the CD45-positive splenic lymphocytes, which remained similar regardless of treatment with cimetidine and DEN. Therefore, cimetidine may not increase the proportion of NK cells, but rather tends to enhance their activity.

Kobayashi et al demonstrated that cimetidine blocks the adhesion of colorectal tumor cells to endothelial cells through the down-regulation of E-selectin cell surface expression (47). In a clinical study, their group also showed cimetidine treatment dramatically improved survival in patients with colorectal cancer expressing high levels of sialyl Lewis antigen, a ligand for E-selectin (13). Although this mechanism may play a crucial role in tumor cell metastasis, it may not be important in the present hepatocarcinogenesis model, as no apparent distant metastasis was found throughout the experimental period.

Glutathione S-transferase (GST) is an enzyme family with multi-molecular forms and multiple functions for the detoxification of drugs (48). Rat GST-P, which belongs to class $p i$ in the species-independent classification of GST, has been shown to be a marker enzyme for rat preneoplastic lesions (48). Rat chemical hepatocarcinogenesis comprises 3 stages; initiation, promotion and progression (49), and GST-P is strongly expressed in rat preneoplastic lesions such as enzyme-altered foci, which emerge in the promotion stage. Preneoplastic enzyme-altered foci have been proposed to play a key role in the process of hepatocarcinogenesis (48). In the present study, cimetidine reduced the percentage of GSTP-positive areas in DEN-treated rat livers. Simultaneously, PCNA-positive cells in both GST-P-positive and -negative areas tended to be decreased by cimetidine treatment, though statistical significance was not reached. A reduction in the number of GST-P-positive preneoplastic hepatocytes by cimetidine treatment may be closely related to a decrease in the number of PCNA-positive hepatocytes. Indeed, cimetidine was reported to inhibit PCNA-positive cells in carcinogeninduced colon cancer model rats (21).

We found that administration of cimetidine reduced the number and size of liver nodules, with a significant difference in the number of liver nodules between groups A and B observed at week 22, but not week 32 . It was considered that the lack of significant difference between the 2 groups after 32 weeks was caused by fusion of the growing liver nodules. At week 32, the maximum diameter of the largest nodule was significantly larger in group A than in group B, while liver weight, which is thought to reflect tumor volume, was also significantly heavier in group A.

In summary, our results showed that cimetidine has an inhibiting effect on hepatocarcinogenesis and we are the first to show the anti-tumor effects of cimetidine on HCCs in vivo. Thus, this classic and safe drug may be suitable for the prevention and treatment of HCC, though additional studies are needed.

\section{Acknowledgements}

We thank the Cell Resource Center for Biochemical Research, Institute of Development, Aging and Cancer, Tohoku University, Sendai, Japan, for kindly providing the YAC-1 cell line. We are also grateful to Dainippon Sumitomo Pharma Co., Ltd., Osaka, Japan, for providing the cimetidine.

\section{References}

1. Befeler AS and Di Bisceglie AM: Hepatocellular carcinoma: diagnosis and treatment. Gastroenterology 122: 1609-1619, 2002.

2. Liu JH, Chen PW, Asch SM, Busuttil RW and Ko CY: Surgery for hepatocellular carcinoma: does it improve survival? Ann Surg Oncol 11: 298-303, 2004.

3. Tarao K, Fujiyama S, Ohkawa S, Miyakawa K, Tamai S, Hirokawa S, Masaki T and Tanaka K: Ursodiol use is possibly associated with lower incidence of hepatocellular carcinoma in hepatitis C virus-associated liver cirrhosis. Cancer Epidemiol Biomarkers Prev 14: 164-169, 2005.

4. Arase Y, Ikeda K, Murashima N, Chayama K, Tsubota A, Koida I, Suzuki Y, Saitoh S, Kobayashi M and Kumada H: The long term efficacy of glycyrrhizin in chronic hepatitis $\mathrm{C}$ patients. Cancer 79: 1494-1500, 1997.

5. Kakizaki S, Sohara N, Sato K, Suzuki H, Yanagisawa M, Nakajima H, Takagi H, Naganuma A, Otsuka T, Takahashi H, Hamada T and Mori M: Preventive effects of vitamin K on recurrent disease in patients with hepatocellular carcinoma arising from hepatitis C viral infection. J Gastroenterol Hepatol 22: 518-522, 2007.

6. Takai K, Okuno M, Yasuda I, Matsushima-Nishiwaki R, Uematsu T, Tsurumi H, Shiratori Y, Muto Y and Moriwaki H: Prevention of second primary tumors by an acyclic retinoid in patients with hepatocellular carcinoma. Updated analysis of the long-term follow-up data. Intervirology 48: 39-45, 2005.

7. Llovet JM, Schwartz M and Mazzaferro V: Resection and liver transplantation for hepatocellular carcinoma. Semin Liver Dis 25: 181-200, 2005.

8. Camma C, Giunta M, Andreone P and Craxi A: Interferon and prevention of hepatocellular carcinoma in viral cirrhosis: an evidence-based approach. J Hepatol 34: 593-602, 2001.

9. Armitage JO and Sidner RD: Antitumour effect of cimetidine. Lancet 1: 882-883, 1979.

10. Tonnesen H, Knigge U, Bulow S, Damm P, Fischerman K, Hesselfeldt P, Hjortrup A, Pedersen IK, Pedersen VM, Siemssen OJ, et al: Effect of cimetidine on survival after gastric cancer. Lancet 2: 990-992, 1988.

11. Adams WJ and Morris DL: Short-course cimetidine and survival with colorectal cancer. Lancet 344: 1768-1769, 1994.

12. Burtin C, Noirot C, Scheinmann P, Galoppin L, Sabolovic D and Bernard P: Clinical improvement in advanced cancer disease after treatment combining histamine and $\mathrm{H} 2$-antihistaminics (ranitidine or cimetidine). Eur J Cancer Clin Oncol 24: 161-167, 1988.

13. Matsumoto S, Imaeda Y, Umemoto S, Kobayashi K, Suzuki H and Okamoto T: Cimetidine increases survival of colorectal cancer patients with high levels of sialyl Lewis-X and sialyl Lewis-A epitope expression on tumour cells. Br J Cancer 86: 161-167, 2002.

14. Matsumoto S: Cimetidine and survival with colorectal cancer. Lancet 346: 115, 1995.

15. Dexeus FH, Logothetis CJ, Sella A, Fitz K, Amato R, Reuben JM and Dozier N: Phase II study of coumarin and cimetidine in patients with metastatic renal cell carcinoma. J Clin Oncol 8: 325-329, 1990.

16. Morton RF, Creagan ET, Cullinan SA, Mailliard JA, Ebbert L, Veeder MH and Chang M: Phase II studies of single-agent cimetidine and the combination N-phosphonacetyl-L-aspartate (NSC-224131) plus L-alanosine (NSC-153353) in advanced malignant melanoma. J Clin Oncol 5: 1078-1082, 1987. 
17. Lefranc F, Yeaton $\mathrm{P}$, Brotchi $\mathrm{J}$ and Kiss R: Cimetidine, an unexpected anti-tumor agent, and its potential for the treatment of glioblastoma (Review). Int J Oncol 28: 1021-1030, 2006.

18. Fujikawa T, Shiraha H, Nakanishi Y, Takaoka N, Ueda N, Suzuki M and Shiratori Y: Cimetidine inhibits epidermal growth factor-induced cell signaling. J Gastroenterol Hepatol 22: 436-443, 2007.

19. Shiota G, Harada K, Ishida M, Tomie Y, Okubo M, Katayama S, Ito $\mathrm{H}$ and Kawasaki $\mathrm{H}$ : Inhibition of hepatocellular carcinoma by glycyrrhizin in diethylnitrosamine-treated mice. Carcinogenesis 20: 59-63, 1999.

20. Gifford RR, Ferguson RM and Voss BV: Cimetidine reduction of tumour formation in mice. Lancet 1: 638-640, 1981.

21. Adams WJ, Lawson JA, Nicholson SE, Cook TA and Morris DL: The growth of carcinogen-induced colon cancer in rats is inhibited by cimetidine. Eur J Surg Oncol 19: 332-335, 1993

22. Kogure K, Ishizaki M, Nemoto M, Kuwano H and Makuuchi M: A comparative study of the anatomy of rat and human livers. J Hepatobiliary Pancreat Surg 6: 171-175, 1999.

23. Squire RA and Levitt MH: Report of a workshop on classification of specific hepatocellular lesions in rats. Cancer Res 35: 3214-3223, 1975.

24. Morris DL and Adams WJ: Cimetidine and colorectal cancer old drug, new use? Nat Med 1: 1243-1244, 1995.

25. Garcia-Cabellero M, Nunezed X, Castro I, Kusche J and Vora Thorbeck L: Histamine metabolism in human breast and colorectal cancer: Its effects on other host tissues. Adv Biosci 89: 273-287, 1993.

26. Jeziorska M, Haboubi NY, Schofield PF and Wooley DE: Mast cell distribution and tumour cell proliferation in colonic carcinoma. Gut 34: 55, 1993.

27. Adams WJ, Lawson JA and Morris DL: Cimetidine inhibits in vivo growth of human colon cancer and reverses histamine stimulated in vitro and in vivo growth. Gut 35: 1632-1636, 1994.

28. Takahashi K, Tanaka S, Furuta K and Ichikawa A: Histamine H2 receptor-mediated modulation of local cytokine expression in a mouse experimental tumor model. Biochem Biophys Res Commun 297: 1205-1210, 2002.

29. Hahm KB, Park IS, Kim HC, Lee KJ, Kim JH, Cho SW and Lee SI: Comparison of antiproliferative effects of 1-histamine-2 receptor antagonists, cimetidine, ranitidine, and famotidine, in gastric cancer cells. Int J Immunopharmacol 18: 393-399, 1996.

30. Lawson JA, Adams WJ and Morris DL: Ranitidine and cimetidine differ in their in vitro and in vivo effects on human colonic cancer growth. Br J Cancer 73: 872-876, 1996.

31. Primrose JN, Miller GV, Preston SR, Gokhale J, Ambrose NS, Ward UM, Mills JG, Ehsanullah RS and Darekar B: A prospective randomised controlled study of the use of ranitidine in patients with gastric cancer. Yorkshire GI Tumour Group. Gut 42: $17-19,1998$.

32. Gifford RR and Tilberg AF: Histamine type-2 receptor antagonist immune modulation. II. Cimetidine and ranitidine increase interleukin-2 production. Surgery 102: 242-247, 1987.

33. Osband ME, Hamilton D, Shen YJ, Cohen E, Shlesinger M, Lavin P, Brown A and McCaffrey R: Successful tumour immunotherapy with cimetidine in mice. Lancet 1: 636-638, 1981.

34. Adams WJ and Morris DL: Pilot study - cimetidine enhances lymphocyte infiltration of human colorectal carcinoma: results of a small randomized control trial. Cancer 80: 15-21, 1997.
35. Lin CY, Bai DJ, Yuan HY, Wang K, Yang GL, Hu MB, Wu ZQ and Li Y: Perioperative cimetidine administration promotes peripheral blood lymphocytes and tumor infiltrating lymphocytes in patients with gastrointestinal cancer: Results of a randomized controlled clinical trial. World J Gastroenterol 10: 136-142, 2004.

36. Kubota T, Fujiwara H, Ueda Y, Itoh T, Yamashita T, Yoshimura T, Okugawa K, Yamamoto Y, Yano Y and Yamagishi H: Cimetidine modulates the antigen presenting capacity of dendritic cells from colorectal cancer patients. Br J Cancer 86: 257-261, 2002.

37. Beer DJ and Rocklin RE: Histamine-induced suppressor-cell activity. J Allergy Clin Immunol 73: 439-452, 1984.

38. Rocklin RE: Histamine-induced suppressor factor (HSF): effect on migration inhibitory factor (MIF) production and proliferation. J Immunol 118: 1734-1738, 1977.

39. Hahm KB, Kim WH, Lee SI, Kang JK and Park IS: Comparison of immunomodulative effects of the histamine-2 receptor antagonists cimetidine, ranitidine, and famotidine on peripheral blood mononuclear cells in gastric cancer patients. Scand J Gastroenterol 30: 265-271, 1995.

40. Siegers CP, Andresen S and Keogh JP: Does cimetidine improve prospects for cancer patients? A reappraisal of the evidence to date. Digestion 60: 415-421, 1999.

41. Hellstrand K and Hermodsson S: Histamine H2-receptormediated regulation of human natural killer cell activity. J Immunol 137: 656-660, 1986.

42. Nishiguchi S, Tamori A, Shiomi S, Enomoto M, Tatsumi N, Koh N, Habu D, Sakaguchi H, Takeda T, Seki S, Nakamura K, Kubo S and Kinoshita H: Cimetidine reduces impairment of cellular immunity after transcatheter arterial embolization in patients with hepatocellular carcinoma. Hepatogastroenterology 50: 460-462, 2003.

43. Nakajima T, Mizushima N and Kanai K: Relationship between natural killer activity and development of hepatocellular carcinoma in patients with cirrhosis of the liver. Jpn J Clin Oncol 17: 327-332, 1987.

44. Chuang WL, Liu HW and Chang WY: Natural killer cell activity in patients with hepatocellular carcinoma relative to early development and tumor invasion. Cancer 65: 926-930, 1990.

45. Taketomi A, Shimada M, Shirabe K, Kajiyama K, Gion T and Sugimachi K: Natural killer cell activity in patients with hepatocellular carcinoma: a new prognostic indicator after hepatectomy. Cancer 83: 58-63, 1998.

46. Lee YS, Choe GY, Kim YI, Park SH, Park IA, Lee MJ and Jang JJ: Correlation of changes in natural killer cell activity and glutathione S-transferase placental form positive hepatocytes in diethylnitrosamine-induced rat hepatocarcinogenesis. J Korean Med Sci 14: 171-174, 1999.

47. Kobayashi K, Matsumoto S, Morishima T, Kawabe T and Okamoto T: Cimetidine inhibits cancer cell adhesion to endothelial cells and prevents metastasis by blocking E-selectin expression. Cancer Res 60: 3978-3984, 2000.

48. Sato K: Glutathione transferases as markers of preneoplasia and neoplasia. Adv Cancer Res 52: 205-255, 1989.

49. Pitot HC: Hepatocyte death in hepatocarcinogenesis. Hepatology 28: $1-5,1998$ 